\title{
Variations in $\mathrm{BCO}_{2}$ Coding Sequence Causing a Difference in Carotenoid Concentration in the Skin of Chickens
}

\section{Yan Wang}

Guangdong Academy of Agricultural Sciences

\section{Shiyi Gan}

Guangdong Academy of Agricultural Sciences

\section{Chenglong Luo}

Guangdong Academy of Agricultural Sciences

Tianfei Liu

Guangdong Academy of Agricultural Sciences

\section{Xiaoling Zhao}

Sichuan Agricultural University

Jie Ma

Guangdong Academy of Agricultural Sciences

Chuxiao Lin

Guangdong Academy of Agricultural Sciences

\section{Dingming Shu}

Guangdong Academy of Agricultural Sciences

Hao Qu ( $\nabla$ qhw03@163.com )

Guangdong Academy of Agricultural Sciences

\section{Research}

Keywords: Yellow skin, Copy number variation, Expression profile, $\beta$-carotene oxygenase 2, Carotenoid

Posted Date: August 7th, 2020

DOI: https://doi.org/10.21203/rs.3.rs-54013/v1

License: (c) (i) This work is licensed under a Creative Commons Attribution 4.0 International License.

Read Full License 


\section{Abstract}

Background: Carotenoid consumption decreases the risk of cancer, osteoporosis, or neurodegenerative diseases through interrupting the formation of free radicals. Carotenoid-pigmented egg yolk, skin, legs, beak, comb, and feathers in broilers give consumers the impression that they are healthier than nonepigmented ones. Deposition of carotenoids in chicken skin makes the skin color turn from white into yellow. The enzyme $\beta$-carotene oxygenase 2 ( $\mathrm{BCO} 2$ ) plays a key role during the degradation process of carotenoids in skin. How does the $\mathrm{BCO} 2$ affects the skin color of chicken, and whether it is the key factor resulted in the phenotypic difference between yellow- and white- skin chickens are still unclear. Three female chickens of the Guangxi Huang and Qingjiao Ma breed were slaughtered and used for carotenoid concentration and $\mathrm{BCO} 2$ expression level analysis. The carotenoid concentration in chicken skin was determined by HPLC. A total of 1054 DNA samples from seven different chicken breeds were genotyped and allele frequencies analysis.

Results: In the present study, we measured the concentration of carotenoids in chicken skin showed that the carotenoid concentration in chicken with a yellow skin was significantly higher than that with white skin chicken. Then we analyzed the expression profile of $\mathrm{BCO} 2$ in different tissues and observed significant differences in gene expression in the back skin between yellow- and white- skin chicken. Scanning the SNPs in $\mathrm{BCO} 2$ gene, it revealed a G/A mutation in exon 6, which was confirmed by PCRRFLP. Copy number variation (CNV) was also detected; the copy number in white yellow skin chicken was almost 2-fold of that than in yellow skin chicken. These results implied that the G/A mutation and CNV in chicken skin may play a key role in regulating the carotenoids degradation.

Conclusions: Generally, reduced expression of the $\mathrm{BCO} 2$ gene due to lower $\mathrm{CVNs}$ may be responsible for the deposition of carotenoids and as a consequence a yellow skin color in yellow skin chicken. One SNP c. $890 \mathrm{~A}>\mathrm{G}$ was found to be associated with the chicken skin color and may be used as a genetic marker in breeding for yellow skin in chicken in the future.

\section{Introduction}

Carotenoids are natural pigments that are synthesized by plants, algae, some bacteria and fungi, and are important source of vitamin A for livestock. In vivo, besides acting as pigments, carotenoids also have other biology functions; they can for instance function as antioxidants that have an important role in protecting DNA from oxidative damage. Oxidative stress has been recognized as the main contributor to the age-related diseases [1] such as atherosclerosis, osteoporosis, obesity, dementia, diabetes, cancer, and arthritis [2, 3]. Carotenoid consumption is associated with a lower risk to develop these diseases by interrupting the propagation of free radicals [4-6]. Animals however cannot synthesize carotenoids de novo, they intake carotenoid from their food [7]. Carotenoids are therefore an important component in well-balanced human diet. Similarly, carotenoids are included in the feed of production animals in a species-specific way to support animal health and achieve a high performance [8]. 
In poultry feed high in carotenoid content leads to carotenoid-pigmented egg yolk, skin, legs, beak, comb, and feathers. The skin color of chickens is in some countries, such as China is an important trait, influencing the choice of consumers in their decision to buy a chicken or not [9]. The skin color of chickens may differ depending on how much of the carotenoid pigment is deposited in the skin. Consumers think that skin pigmentation is an important health indicator in poultry, as a weak health greatly reduces the absorption of carotenoids. So poultry farmers add carotenoids to chicken feed to achieve the desired color to satisfy customers preference. In chicken, the capacity to accumulate carotenoids in skin is however mostly genetically determined [10]. The accumulation of carotenoids makes that the skin has a yellow color, while enzymatic degradation of carotenoids provides the skin with a white appearance.

There are two enzymes involved in carotenoid metabolism, namely $\beta$-carotene 15,15 '-monooxygenase 1 (BCM01) and $\beta$-carotene oxygenase 2 (BCO2). BCMO1 is responsible for the oxidative cleavage of $\beta$ carotene into 2 retinal molecules [2, 3], while $\mathrm{BCO} 2$ can mediate the degradation of carotenoid into colorless substances [4-7]. The expression of these enzymes is tissue dependent. Recently research has demonstrated that $\mathrm{BCOM} 1$ and $\mathrm{BCO} 2$ work together in gut and liver in carotenoid degradation, while other tissues e.g. adipose tissue, depend on BCO2 for carotenoid metabolism $[7,11]$.

Several previous studies have revealed that point mutations in the $\mathrm{BCO} 2$ gene can influence the deposition of carotenoids in the skin, thus influencing skin color. For example, the $A G>A$ (chr24:6,268,434 bp) mutation in the $B C O 2$ gene is associated with a yellow skin trait in chicken [10], while a nonsense mutation (c. $196 \mathrm{C}>\mathrm{T}$ ) leaving the $\mathrm{BCO} 2$ gene inactive, is associated with accumulation of carotenoids in adipose tissue in sheep [7]. Furthermore, mutations in $\mathrm{BCO} 2$ have been shown to affect the concentration of carotenoids in bovine milk [12]. Above all, $\mathrm{BCO} 2$ is a strong candidate gene to affect the deposition of carotenoids. The aim of this investigation is to study differences in $B C O 2$ expression between yellow skin and white skin chicken. This will help us to understand the molecular mechanisms involved in skin carotenoid metabolism and provide a valuable theoretical basis for the selection of the skin trait during the selective breeding of chickens. For marketing of poultry products, in a number of countries in the world chicken skin color is a trait that influences consumer behavior. A bright yellow skin color is often associated with freshness and health and has become an indicator of high-quality products. A uniform and good pigmentation generally means good health and good practical hygienic conditions [8].

\section{Materials And Methods}

\section{Ethics Statement}

Our study was approved by the Animal Care Committee of the Institute of Animal Science, Guangdong Academy of Agricultural Sciences (Guangzhou, People's Republic of China) with approval number GAASIAS-2009-73. All birds were housed in individual battery cages with ad libitum access to food and water and humanely euthanized. 


\section{Samples}

Two breeds of chicken were used, the Guangxi Huang (S4) chickens were bred by the Institute of Animal Science, Guangdong Academy of Agricultural Sciences (Guangzhou, China). The Qingjiao Ma (Q) chickens were bred by the Sichuan Agricultural University (Ya'an, China), and kindly providing the samples used in this study. All birds had free access to feed and water.

At the age of 91 days blood samples were collected in $1.5 \mathrm{~mL}$ tubes with $1.5 \%$ EDTA and stored at $-20^{\circ} \mathrm{C}$. Birds were humanely euthanized and tissue samples including heart, liver, spleen, lungs, kidney, muscular stomach, glandular stomach, intestine, breast muscle, ovary, cerebrum, cerebellum, hypothalamus, hypophysis and back skin were collected. Tissue samples were collected for RNA isolation were put in $1.5 \mathrm{~mL}$ tubes with RNA later (Sigma-Aldrich, MO, USA) and stored at $-20^{\circ} \mathrm{C}$. Skin tissue samples used for DNA isolation were stored at $-80^{\circ} \mathrm{C}$.

The DNA of reference breeds were collected at the Institute of Animal Science, Guangdong Academy of Agricultural Sciences. A total of 1054 DNA samples from seven different chicken breeds were genotyped and allele frequencies were determined: Huiyang Beard, Silkies, Mahuang, Youxi Ma, Qingjiao Ma, Fastgrowing Lingnanhuang Line A and Guangxi Yellow Chicken. Samples for RNA isolation and DNA isolation were stored as described above until further use.

\section{Measurement of Carotenoid Concentration in Chicken Skin}

For the measurement of the carotenoid concentration in chicken skin, $0.5 \mathrm{~g}$ back skin tissue was add to $5 \mathrm{~mL}$ mixture reagent $\left(\mathrm{CHCL}_{3}: \mathrm{CH}_{3} \mathrm{OH}=2: 1\right)$ in a $50 \mathrm{~mL}$ tube and homogenized. Then $5 \mathrm{~mL}$ mixture reagent was added to the homogenate followed by $2 \mathrm{~mL} 0.9 \%(8.5 \mathrm{~g} / \mathrm{L}) \mathrm{NaCl}$ after which the tube was vortexed for 2 minutes. Samples were centrifuge at $648 \mathrm{~g}$ for 10 minutes at $4{ }^{\circ} \mathrm{C}$. After centrifugation, the $\mathrm{CHCL}_{3}$ layer was transferred to a new tube, while the water layer was transferred to another tube with $5 \mathrm{~mL}$ hexane, vortexed for 2 minutes and centrifuged again at $648 \mathrm{~g}$ for 10 minutes at $4^{\circ} \mathrm{C}$. From this tube the hexane layer was removed and added to the tube with the $\mathrm{CHCL}_{3}$ phase $[13,14]$. The content of the tube was put in a water bath at $50^{\circ} \mathrm{C}$, and being dried by nitrogen using Rotary Evaporator (RE-3000A, Shanghai Yarong Biochemistry Instrument factory, Shanghai, China); the formed pellet was dissolved in $0.15 \sim 5 \mathrm{~mL}$ ethanol after which 50ul of the ethanol samples was analyzed using High Performance Liquid Chromatography (LC-20AD, SHIMAZU Inc., Kyoto, Japan). Lutein and zeaxanthin were used as internal standard (Guangzhou Juyuan Biochemical Co., Guangzhou, China), and measured at a wavelength of $445 \mathrm{~nm}$ and $451 \mathrm{~nm}$, respectively. Differential carotenoid concentrations in chicken skin, between the Guangxi Huang and Qingjiao Ma breeds, was determined using a t-test with SAS 8.0 software (SAS Institute, Cary, NC, USA).

\section{Primers}

Primer pairs were designed for 18 fragments (F1/R1-F18/R18) together responsible for amplification of the complete CDS of the $\mathrm{BCO} 2$ gene. These included primers for PCR-RFLP: YSD-F/R, primers for RT-PCR: 
BCO2-F/R and the housekeeping genes GAPDH-F/R and $\beta$-actin-F/R. TaqMan Real-time PCR: probes (BCO2-IN2, SOX5-IN2, shown in table 2) and primers (BCO2-C-F/R, SOX5-F/R). All primers were synthesis by Sangon Biotech (Shanghai) Co., Ltd. The primer sequences are shown in Table 1.

\section{SNP Scanning and Genotyping}

DNA was isolated from whole blood and tissue samples by SDS-proteinase K (ThermoScientific, Shanghai, China). The 18 fragments were amplified by PCR, using DNA as template. To check whether the correct products were amplified, the PCR products were sequenced (Sangon Biotech (Shanghai) Co., Shanghai, China). The sequences were aligned between the two breeds to identify the SNP site. Genotyping by PCR-RFLP and treatment with the restriction enzyme Sdul (ThermoScientific, Shanghai, China) made it possible to recognize the SNP site.

\section{Real-time PCR}

Three female chickens from 91-days old of the Guangxi Huang and Qingjiao Ma breed were used for this analysis. Fifteen tissue heart, liver, spleen, lungs, kidney, gizzard (muscle part stomach), glandular stomach, intestine, breast muscle, ovary, cerebrum, cerebellum, hypothalamus, hypophysis and back skin were collected. Tissues were weighed (approximately $0.2 \mathrm{~g}$ if tissue was used), grounded into a powder in liquid nitrogen and homogenized in $2 \mathrm{~mL}$ of TRIzol (Life Technologies, Rockville, MD USA) using a handheld electric homogenate instrument (Germany, Staufen, IKA). The homogenized samples were left for $5 \mathrm{~min}$ at room temperature and then centrifuged at 12,000 rpm (representative g value) at $4^{\circ} \mathrm{C}$ for 10 min. Total RNA was isolated using the RNAiso Plus kit (Takara Bio Inc., Dalian, China) according to the manufacturer's instructions. The amount and quality of the samples was estimated using the NanoDrop ND-1000 spectrophotometer (ThermoScientific, MA, USA) and gel electrophoresis (Bio-Rad Laboratories, SYSTEM GelDoc XR+, California, USA ). First-strand cDNA synthesis and reverse transcriptase PCR were performed as described in the instructions for the PrimeScript ${ }^{\mathrm{TM}}$ II reagent Kit with gDNA Eraser (TaKara, Dalian, China). Primer pairs BCO2-F/BCO2-R (Table 1) were used to determine the relative expression values of the $B C O 2$ gene by $q P C R$. The PCR amplifications were performed in $20 \mu \mathrm{L}$ reaction volumes comprising $0.5 \mu \mathrm{L}$ of chicken cDNA, $0.5 \mu \mathrm{L}$ of each primer and $10 \mu \mathrm{L}$ of SYBR Green Real-time PCR Master Mix (TOYOBO, Tokyo, Japan) in a LightCycler 480 Real-Time PCR System (Roche Applied Science, Indianapolis, IN, USA). The PCR conditions were: $95^{\circ} \mathrm{C}$ for $1 \mathrm{~min}$, followed by 40 cycles of $95^{\circ} \mathrm{C}$ for $15 \mathrm{~s}$, $58^{\circ} \mathrm{C}$ for $15 \mathrm{~s}$, and $72^{\circ} \mathrm{C}$ for $20 \mathrm{~s}$. The level of fluorescence was used to calculate the threshold cycle (Ct) value for each sample. The relative gene expression levels were analyzed using the comparative $\mathrm{Ct}$ method, in which housekeeping genes $\beta$-actin and GAPDH (Table 1) were used as internal controls and the geometric averaging of those two internal control genes was calculated according a previously published method [15]. The geometric mean of 2 reference genes according to the $\Delta C T$ [11], $2^{-\Delta C T}$ method were used to calculate the expression level [16]. Expression abundances of $B C O 2$ gene in 15 tissue samples, between the Guangxi Huang and Qingjiao Ma breeds, were determined and analyzed using a ttest with SAS 8.0 software (SAS Institute, Cary, NC, USA). 


\section{TaqMan Real-time PCR}

Primer pairs BCO2-C-F/BCO2-C-R, SOX5-F/SOX5-R and probes BCO2-IN2, SOX5-IN2 (Table 1) were used to perform genomic copy number analysis by TaqMan Real-time PCR. Target probes were marked and labeled with 5'6-FAM/3'BHQ1, the reference probe located in an exon of SOX5 were labeled with 5'HEX/3'TAMRA (Sangon Biotech (Shanghai) Co., Shanghai, China). TaqMan RT-PCR system (TAKARA Inc.): Premix Ex Taq (Probe qPCR) (2x) $10 \mu \mathrm{L}$, PCR 2 Forward Primer $0.4 \mu \mathrm{L} / \mathrm{each}, 2$ PCR Reverse Prime $0.4 \mu \mathrm{L}$ /each, TaqMan ${ }^{\circledR}$ Probe1 $0.6 \mu \mathrm{L}$, TaqMan ${ }^{\circledR}$ Probe2 $0.6 \mu \mathrm{L}$, DNA $1 \mu \mathrm{L}, \mathrm{ddH}_{2} \mathrm{O} 6.2 \mu \mathrm{L}$, Total, $20 \mu \mathrm{L}$. Program: pre-degeneration, $95^{\circ} \mathrm{C} 30 \mathrm{~s} 20^{\circ} \mathrm{C} / \mathrm{s}, 1$ Cycle; PCR, $95^{\circ} \mathrm{C} 5 \mathrm{~s} 20^{\circ} \mathrm{C} / \mathrm{s}, 60^{\circ} \mathrm{C} 20 \mathrm{~s} 20^{\circ} \mathrm{C} / \mathrm{s}, 40$ Cycles; cooling, $50^{\circ} \mathrm{C} 30 \mathrm{~s}$ (speed $2.2^{\circ} \mathrm{C} / \mathrm{s}$ ), 1 cycle. Data was analyzed using the $\Delta \Delta \mathrm{Ct}$ method by first normalizing the target $\mathrm{Ct}$ value to the reference $\mathrm{Ct}$ value within a sample [17]. Error bars represent the minimum and maximum estimated copy number as calculated from technical replicates of each sample.

\section{Results}

\section{Carotenoid Concentration in Chicken Skin and Difference of BCO2 Expression Level in Tissues}

The carotenoid concentration in chicken skin was determined by HPLC. No $\beta$-carotene was detected, but the lutein and zeaxanthin content of yellow skin chicken-S4 were significantly $(P<0.01)$ higher than that of white skin chicken-Q (Figure 1).

$B C O 2$ expressed in all tissues. $\mathrm{BCO} 2 \mathrm{had}$ a lower expression level in liver, intestine, back skin, breast muscle, lungs and ovary in the Guangxi Huang (S4) compared with those in Qingjiao Ma (Q). Expression levels of $\mathrm{BCO} 2$ were much higher in the hypophysis in both breeds compared with those in the other tissues (Figure 2).

\section{Single Nucleotide Polymorphism scanning in BCO2 Coding Sequence}

Scanning for SNPs in the $B C O 2$ CDS gene by TA-cloning and sequencing, did not lead to previously described SNPs for this gene. However, a G/A mutation was found in exon 6 (c.890A>G, GenBank accession No. XM_417929.6). The Qingjiao Ma (Q) breed had two genotypes: AA and AG, whereas the Guangxi Huang (S4) breed was only homozygous for the GG genotype (Figure 3). This result was confirmed by PCR-RFLP in other chicken breeds (Table 3). The allelic frequencies of the SNP c.890A>G in white skin and yellow skin chicken breeds were notably different. As shown in Table 3, allele A was predominant in those breeds with a white skin, such as Silkies, Qingjiao Ma, Youxi Ma and Mahuang Chicken. Allele $\mathrm{G}$ was predominant in yellow skin breeds, including Huiyang Beard, Fast-growing Lingnanhuang Line A and Guangxi Huang Chicken.

\section{Difference in Copy Number Variation between Yellow Skin Chicken-S4 and White Skin Chicken-Q}

Copy number variation of the $\mathrm{BCO} 2$ gene in back skin tissue was investigated between two breeds. It appeared that the copy number of $\mathrm{BCO} 2$ in the Qingjiao Ma S4 breed is almost 2-fold higher than in the 


\section{Discussion}

Carotenoids are an important factor for growth and health of birds, color and therefore carotenoid additives and vitamin A supplements may be added to poultry feed formulations. As an alternative for this some studies have used established high-carotenoid maize as an alternative for these supplements in laying hens and broilers [18-20]. Our results show that carotenoids are deposited in the skin of yellow skin chicken, while in white skin chicken there is almost no deposition of carotenoids, as no $\beta$-carotene was detected, while the lutein and zeaxanthin were detected in chicken skin. In line with these observations there was no expression of the $\mathrm{BCO} 2$ gene in the skin of the Guangxi Huang (yellow skin) breed, in contrast to the Qingjiao Ma (white skin) breed. The absence of $B C O 2$ expression in the skin of the Guangxi Huang breed was specific for the skin as no differences in $\mathrm{BCO} 2$ gene expression were observed among the two breeds in any of the other tissues investigated. Because BCO2 cleaves orange/yellow carotenoids into colorless apocarotenoids, it is concluded that $\mathrm{BCO} 2$ is the gene that regulates the deposition of carotenoids in chicken skin. However, adding more color additives to poultry diets does not induce a change from white skin to yellow skin color, indicating that coloring of the chicken skin is more complex. Furthermore, the presence of zeaxanthin in the feed might interfere with the absorption of b-carotene, as chickens fed on diets with low levels of zeaxanthin accumulated higher levels of retinol in the liver [21].

Scanning for the presence of skin color related SNPs between yellow skin and white skin chicken, did not lead to the identification of previously reported SNPs [10]. An explanation for this discrepancy may be related to differences in the chicken breeds used in the two studies. Instead, we found a new SNP in the $B C O 2$ gene, which when tested in other chicken breeds, may be used as a genetic marker associated with skin color. The absence of $B C O 2$ expression in the skin of the Guangxi Huang breed is typical for the skin, as $\mathrm{BCO} 2$ expression was observed in other tissues in both the Guangxi Huang and Qingjiao Ma breeds and was for instance very high in the hypophysis of both breeds.

Several reports indicate that copy number variations are highly associated with specific phenotypes. For examples, CNVs in intron 1 of the SOX5 gene cause the Pea-comb phenotype in chickens [22]; while two duplications containing EDN3 result in an abnormal skin pigmentation phenotype in silkie breed [17]. CNVs in the testis-specific Y-encoded protein (TSPY) gene have been linked to prostate cancer and human male infertility [23-25]. CNVs in the stem cell factor receptor (KIT) gene are linked to porcine white coat color [26], while CNVs in the agouti signaling protein (ASIP) gene influences coat color of goat breeds [27]. We detected in the present study CNVs in BOC2, the copy number in the Qingjiao Ma (white skin chicken) being almost 2-fold larger than in the Guangxi Huang (yellow skin chicken) breed, suggesting that a lower CNV may lead to down-regulation of $B C O 2$ expression.

In the present study, we focused on CNVs in the coding sequence of the $B C O 2$ gene. Despite our observations one has to keep in mind that CNVs may not be the only cause of differences in $\mathrm{BCO} 2$ gene 
expression between the Qingjiao Ma and Guangxi Huang chicken breeds. There may be other factors that can be responsible for the reduced expression of the $\mathrm{BCO} 2$ gene expression in the Guangxi Huang chicken breed, such as DNA methylation [28-30], histone modification [31-33] and UTR function and thus translational modification [34,35]. Additional experiments need to be performed to elucidate the specific difference in $\mathrm{BCO} 2$ expression in the skin of Qingjiao Ma and Guangxi Huang chicken breeds without differences in gene expression in any other tissue.

\section{Conclusion}

In conclusion, reduced expression of the $\mathrm{BCO} 2$ gene due to lower CVNs may be responsible for the deposition of carotenoids and as a consequence a yellow skin color in Guangxi Huang chickens. One SNP c.890A $>G$ was found to be associated with the chicken skin color and may possibly in the future used as a genetic marker in breeding for yellow skin in chicken.

\section{Declarations}

\section{Acknowledgments}

We gratefully acknowledge Sichuan Agricultural University for Qingjiao Ma (Q) chickens sampling, and Guangzhou Juyuan Biochemical Co. for carotenoid concentration determination.

\section{Authors' contributions}

YW analyzed samples, completed statistical analysis, interpreted data, and was the primary author; YW, SYG and CXL conducted all trial; YW and SYG wrote the manuscript; YW, CLL, DMS and HQ designed the study and modified manuscript; HQ, TFL, JM and XLZ collected samples. All authors read and approved the final manuscript.

\section{Funding}

This work was supported by the National Natural Science Foundation of China (Grant No. 31301968), the "Youth Top-notch Talent on Science \& Technology" of Guangdong Province Special Support Program (2016TQ03N898), Special Fund for Scientific Innovation Strategy-Construction of High Level Academy of Agriculture Science (R2017PY-QY007) and the China Agriculture Research System (CARS-41).

\section{Availability of data and materials}

All data generated or analyzed during this study are included within this article.

\section{Ethics approval and consent to participate}

The experimental proposals and procedures for the care and treatment of the chickens were approved by the Animal Care Committee of the Institute of Animal Science, Guangdong Academy of Agricultural 
Sciences (Guangzhou, People's Republic of China) with approval number GAAS-IAS-2009-73.

\section{Consent for publication}

Not applicable

\section{Competing interests}

The authors declare that they have no competing interests.

\section{Author details}

${ }^{1}$ State Key Laboratory of Livestock and Poultry Breeding, Guangdong Key Laboratory of Animal Breeding and Nutrition, Institute of Animal Science, Guangdong Academy of Agricultural Sciences, Guangzhou 510640, People's Republic of China;

${ }^{2}$ Farm Animal Genetic Resources Exploration and Innovation Key Laboratory of Sichuan Province, Sichuan Agricultural University, Chengdu Campus, Chengdu 611130, People's Republic of China;

\section{References}

1. Giudetti AM, Salzet M, Cassano T. Oxidative stress in aging brain: Nutritional and pharmacological interventions for neurodegenerative disorders. Oxid. Med. Cell. Longev. 2018; doi: $10.1155 / 2018 / 3416028$.

2. Tan BL, Norhaizan ME, Huynh K, Heshu SR, Yeap SK, Hazilawati H, et al. Water extract of brewers' rice induces apoptosis in human colorectal cancer cells via activation of caspase- 3 and caspase-8 and downregulates the $\mathrm{Wnt} / \beta$-catenin downstream signaling pathway in brewers' ricetreated rats with azoxymethane-induced colon carcinogenesis. BMC Complement. Altern. Med. 2015;15:205.

3. Liu Z, Zhou T, Ziegler AC, Dimitrion P, Zuo L. Oxidative stress in neurodegenerative diseases: From molecular mechanisms to clinical applications. Oxid. Med. Cell. Longev. 2017;20.

4. Tan BL, Norhaizan ME. Carotenoids: How effective are they to prevent age-related diseases? Molecules. 2019;24(9):1801.

5. Chang J, Zhang Y, Li Y, Lu K, Shen Y, et al. NrF2/ARE and NF-KB pathway regulation may be the mechanism for lutein inhibition of human breast cancer cell. Future Oncol. 2018;14:719-726.

6. Tuzcu M, Orhan C, Muz OE, Sahin N, Juturu V, Sahin K. Lutein and zeaxanthin isomers modulates lipid metabolism and the inflammatory state of retina in obesity-induced high-fat diet rodent model. BMC Ophthalmol. 2017;17:129.

7. VåGE DI, Boman IA. A nonsense mutation in the beta-carotene oxygenase 2 (BCO2) gene is tightly associated with accumulation of carotenoids in adipose tissue in sheep (Ovis aries). BMC Genetics. 2010; 11(1):10. 
8. Langi P, Kiokias S, Varzakas T, Proestos C. Carotenoids: From plants to food and feed industries. Methods Mol Biol. 2018;1852:57-71.

9. Jin S, Lee JH, Seo DW, Cahyadi M, Choi NR, Heo KN, et al, A major locus for quantitatively measured shank skin color traits in korean native chicken. Asian-Australas J Anim Sci. 2016; 29(11):1555-1561.

10. Eriksson J, Larson G, Gunnarsson U, Bed'hom B, Tixier-Boichard M, Strömstedt L, et al. Identification of the yellow skin gene reveals a hybrid origin of the domestic chicken. Plos Genetics. 2008; 4(2):e1000010. doi: 10.1371/journal.pgen.1000010

11. Borel P. Genetic variations involved in interindividual variability in carotenoid status. Molecular Nutrition \& Food Research. 2012; 56(2):228-240.

12. Berry SD, Davis SR, Beattie EM, Thomas NL, Burrett AK, Wardet HE et al. Mutation in bovine betacarotene oxygenase 2 affects milk color. Genetics. 2009; 182(3):923-926.

13. Ribaya-Mercado JD, Holmgren SC, Fox JG, Russell RM. Dietary beta-carotene absorption and metabolism in ferrets and rats. J Nutr. 1989; 119(4):665-668.

14. Ribaya-Mercado JD, Fox JG, Rosenblad WD, Blanco MC, Russell RM. Beta-carotene, retinol and retinyl ester concentrations in serum and selected tissues of ferrets fed beta-carotene. J Nutr. 1992; 122(9):1898-903.

15. Vandesompele J, De Preter K, Pattyn F, Poppe B, Van Roy N, De Paepe A, et al. Accurate normalization of real-time quantitative RT-PCR data by geometric averaging of multiple internal control genes. Genome Biol. 2002; doi: 10.1186/gb-2002-3-7-research0034

16. Schmittgen TD, Livak KJ. Analyzing real-time PCR data by the comparative $C(T)$ method. Comparative Study. Nat Protoc. 2008; 3(6):1101-1108.

17. Dorshorst B, Molin AM, Rubin CJ, Johansson AM, Strömstedt L, Pham MH, et al. A complex genomic rearrangement involving the endothelin 3 locus causes dermal hyperpigmentation in the chicken. PLoS Genet, 2011;7(12):e1002412. doi: 10.1371/journal.pgen.1002412.

18. Moreno JA, Díaz-Gómez J, Nogareda C, Angulo E, Sandmann G, Portero-Otin M, et al. The distribution of carotenoids in hens fed on biofortified maize is influenced by feed composition, absorption, resource allocation and storage. Sci Rep. 2016; 6:35346.

19. Nogareda C, Moreno JA, Angulo E, Sandmann G, Portero M, Capell T, et al. Carotenoid-enriched transgenic corn delivers bioavailable carotenoids to poultry and protects them against coccidiosis. Plant Biotechnol J. 2016; 14:160-168.

20. Díaz-Gómez J, Moreno JA, Angulo E, Sandmann G, Zhu C, Ramos AJ, et al. High-carotenoid biofortified maize is an alternative to color additives in poultry feed. Anim Feed Sci Technol. 2017; 231:38-46.

21. Díaz-Gómez J, Moreno JA, Angulo E, Sandmann G, Zhu C, Capell T, et al. Provitamin A carotenoids from an engineered high-carotenoid maize are bioavailable and zeaxanthin does not compromise $\beta$ carotene absorption in poultry. Transgenic Res. 2017; 26(5):591-601.

22. Wright $D$, Boije $H$, Meadows J, Bed'hom B, Gourichon D, Vieaud A, et al. Copy number variation in intron 1 of SOX5 causes the Pea-comb phenotype in chickens. PLoS Genet. 2009; 5(6):e1000512. 
doi: 10.1371/journal.pgen.1000512.

23. Hamilton CK, Favetta LA, Di Meo GP, Floriot S, Perucatti A, Peippo J, et al. Copy number variation of testis-specific protein, Y-encoded (TSPY) in 14 different breeds of cattle (Bos taurus). Sex Dev. 2009; 3(4):205-13.

24. Vijayakumar S, Hall DC, Reveles XT, Troyer DA, Thompson IM, Garcia D, et al. Detection of recurrent copy number loss at Yp11.2 involving TSPY gene cluster in prostate cancer using array-based comparative genomic hybridization. Cancer Res. 2006; 66(8):4055-64.

25. Seo BY, Park EW, Ahn SJ, Lee SH, Kim JH, Im HT, et al. An accurate method for quantifying and analyzing copy number variation in porcine KIT by an oligonucleotide ligation assay. BMC Genet. 2007; 8:81. doi: 10.1186/1471-2156-8-81.

26. Fontanesi L, Beretti F, Riggio V, Gómez González E, Dall'Olio S, Davoli R, et al. Copy number variation and missense mutations of the agouti signaling protein (ASIP) gene in goat breeds with different coat colors. Cytogenet Genome Res. 2009; 126(4):333-47.

27. Clifford RL, Fishbane N, Patel J, Maclsaac JL, McEwen LM, Fisher AJ, et al. Altered DNA methylation is associated with aberrant gene expression in parenchymal but not airway fibroblasts isolated from individuals with COPD. Clin Epigenetics. 2018; 10:32. doi: 10.1186/s13148-018-0464-5.

28. Colicchio JM, Miura F, Kelly JK, Ito T, Hileman LC. DNA methylation and gene expression in Mimulus guttatus. BMC Genomics. 2015; 16(1):507. doi: 10.1186/s12864-015-1668-0.

29. Jones PA, Takai D. The role of DNA methylation in mammalian epigenetics. Science. 2001; 293(5532):1068-70.

30. Rintisch C, Heinig M, Bauerfeind A, Schafer S, Mieth C, Patone G, et al. Natural variation of histone modification and its impact on gene expression in the rat genome. Genome Res. 2014; 24(6):942-53.

31. Sundar IK, Rahman I. Gene expression profiling of epigenetic chromatin modification enzymes and histone marks by cigarette smoke: implications for COPD and lung cancer. Am J Physiol Lung Cell Mol Physiol. 2016; 311(6):L1245-L1258. doi: 10.1152/ajplung.00253.2016.

32. Wang L, Zhang F, Rode S, Chin KK, Ko EE, Kim J, et al. Ethylene induces combinatorial effects of histone H3 acetylation in gene expression in Arabidopsis. BMC Genomics. 2017; 18(1):538. doi: 10.1186/s12864-017-3929-6.

33. Wongfieng W, Jumnainsong A, Chamgramol Y, Sripa B, Leelayuwat C. 5'-UTR and 3'-UTR Regulation of MICB Expression in Human Cancer Cells by Novel microRNAs. Genes (Basel). 2017; 8(9):213. doi: 10.3390/genes8090213.

34. Larsen CA, Howard MT. Conserved regions of the DMD 3' UTR regulate translation and mRNA abundance in cultured myotubes. Neuromuscul Disord. 2014; 24(8):693-706. doi: 10.1016/j.nmd.2014.05.006.

\section{Tables}

Table 1. Primer sequences

Page $11 / 18$ 


\begin{tabular}{|c|c|c|c|}
\hline Name & Sequence $\left.₫ 5^{\prime}-3^{\prime}\right)$ & annealing temperature $\left({ }^{\circ} \mathrm{C}\right)$ & Product length $₫ \mathrm{bp} \otimes$ \\
\hline F1 & GTGAAGTTGAATAAAAGCAG & 52 & 1458 \\
\hline R1 & TGAGGCAGATACCTAAAGA & & \\
\hline F2 & CTGGAAGGTCAGTTTGGGTG & 55 & 1353 \\
\hline R2 & AGATGGTGCGGGAGGAGA & & \\
\hline F3 & ATGTGCTCCCTTTGCTCC & 56 & 1880 \\
\hline R3 & CTCGTTCCATCTAGCCAGGAGATTC & & \\
\hline F4 & TTTGTCTGTTCTTTGCTTCA & 52 & 1570 \\
\hline R4 & ATCAGACAGGTACTTGTAGAGAC & & \\
\hline F5 & GGTTGTGTCTTGGTGCATT & 58 & 1644 \\
\hline R5 & ААССАССААСАТССТСТТСС & & \\
\hline F6 & GGGCACTAATGTTGGGA & 52 & 1269 \\
\hline R6 & AAAGGAAAGAAAGGGAGA & & \\
\hline F7 & TGCTCTTCATGCTTCACT & 55 & 1580 \\
\hline R7 & TTCTAАТАСТААСТССАСССТG & & \\
\hline F8 & GATACCAGGGTGGAGTTA & 55 & 981 \\
\hline R8 & GTAGTGAGCCATTTAGGG & & \\
\hline F9 & GCAGACTGTGGAGGAGAC & 52 & 1757 \\
\hline R9 & CAGGAAGGGAAGGATTAG & & \\
\hline F10 & CACTTGGTCCCAGTTTGT & 52 & 1733 \\
\hline R10 & ССТTТСТССАТTTGССТА & & \\
\hline F11 & CCCACTGTAGTAGGCAAAT & 55 & 649 \\
\hline R11 & GAAGGGTAGGGACTGATG & & \\
\hline F12 & TCTCGGTTCACTGTCTTG & 52 & 1432 \\
\hline R12 & ACCTGGGAAATCTGTTGT & & \\
\hline F13 & TGGCAAATCTGATTAGTTC & 52 & 1153 \\
\hline R13 & GCTGTGATAGTAGGAGGGT & & \\
\hline F14 & GTCGAACTGCAATGAGACC & 55 & 1173 \\
\hline R14 & AAATAACTCAGCCAGCATG & & \\
\hline
\end{tabular}




\begin{tabular}{|c|c|c|c|}
\hline F15 & TGAGGAAGAGTGGAGCAG & 52 & 1876 \\
\hline R15 & AAGCCGTTAGCACATACC & & \\
\hline F16 & GGAAGAATCTGAACCCTC & 55 & 1163 \\
\hline R16 & TTATCACCACСАССАСТC & & \\
\hline F17 & GCCCTTGAGTGGTGGTGGT & 55 & 1961 \\
\hline R17 & GCCTTGGCATAATGTAAAGTTGTA & & \\
\hline F18 & AGTGCTTTCCTGCTTGTC & 52 & 513 \\
\hline R18 & TCССTССTTGTGCTTTAC & & \\
\hline YSD-F & TCCTCTGATTGCTTTACTGACTTG & 60 & 444 \\
\hline YSD-R & GGGAAGGAGGTATCATTGGAGA & & \\
\hline $\mathrm{BCO}-\mathrm{F}$ & ACTGGACCAAGTTTGTTGCCGT & 58 & 192 \\
\hline $\mathrm{BCO} 2-\mathrm{R}$ & GTTGGAGCAATGGAGCATAGCA & & \\
\hline GAPDH-F & GGTGAAAGTCGGAGTCAACGG & 59 & 108 \\
\hline GAPDH-R & TCGATGAAGGGATCATTGATGGC & & \\
\hline ACTB-F & CCCCAAAGCCAACAGAGAGA & 59 & 158 \\
\hline ACTB-R & GGTGGTGAAGCTGTAGCCTCTC & & \\
\hline BCO2-C-F & AAGCCCATTTCTGAAGGGATAAA & 60 & 84 \\
\hline $\mathrm{BCO} 2-\mathrm{C}-\mathrm{R}$ & ACCTACCTTCCCAGTGCGTTT & & \\
\hline SOX5-F & GCCACCGCAGGTGTTGTT & 60 & 94 \\
\hline SOX5-R & GGCTGCTGGACACACTTGAG & & \\
\hline
\end{tabular}

Table 2. Probe sequences for TaqMan RT-PCR

\begin{tabular}{|lll|}
\hline Name & sequence & Marker \\
\hline BCO2-IN2 & AGCCTCAGTACAACACTCGCTTCCACGT & 5'6-FAM,3'BHQ1 \\
SOX5-IN2 & AATGCCTTCCCCACATCTGCCCTC & 5'HEX,3'TAMRA \\
\hline
\end{tabular}

Table 3. Allelic frequencies for the SNP c.890A $>\mathrm{G}$ in the $\mathrm{BCO} 2$ gene in 8 chicken breeds 


\begin{tabular}{|llllllll|}
\hline Breeds $^{1}$ & No. of birds & \multicolumn{3}{c|}{ Genotypic number } & \multicolumn{2}{c|}{ Allelic frequency } \\
\cline { 2 - 7 } & & AA & AG & GG & A & G \\
\hline Qingjiao Ma & 60 & 60 & 0 & 0 & 1.000 & 0.000 \\
\hline Guangxi Huang & 60 & 0 & 0 & 60 & 0.000 & 1.000 \\
\hline Youxi Ma & 44 & 29 & 15 & 0 & 0.830 & 0.170 \\
\hline Silkies & 640 & 640 & 0 & 0 & 1.000 & 0.000 \\
\hline Huiyang Beard & 60 & 0 & 0 & 60 & 0.000 & 1.000 \\
\hline Fast-growing Lingnanhuang Line A & 60 & 0 & 0 & 60 & 0.000 & 1.000 \\
\hline Mahuang with black shank & 78 & 74 & 4 & 0 & 0.974 & 0.026 \\
\hline Mahuang with navy shank & 52 & 0 & 0 & 52 & 0.000 & 1.000 \\
\hline
\end{tabular}

${ }^{1}$ Yellow skin chicken breeds: Huiyang Beard, Fast-growing Lingnanhuang Line A and Guangxi Huang Chicken. White skin chicken breeds: Silkies, Qingjiao Ma, Youxi Ma and Mahuang Chicken.

\section{Figures}




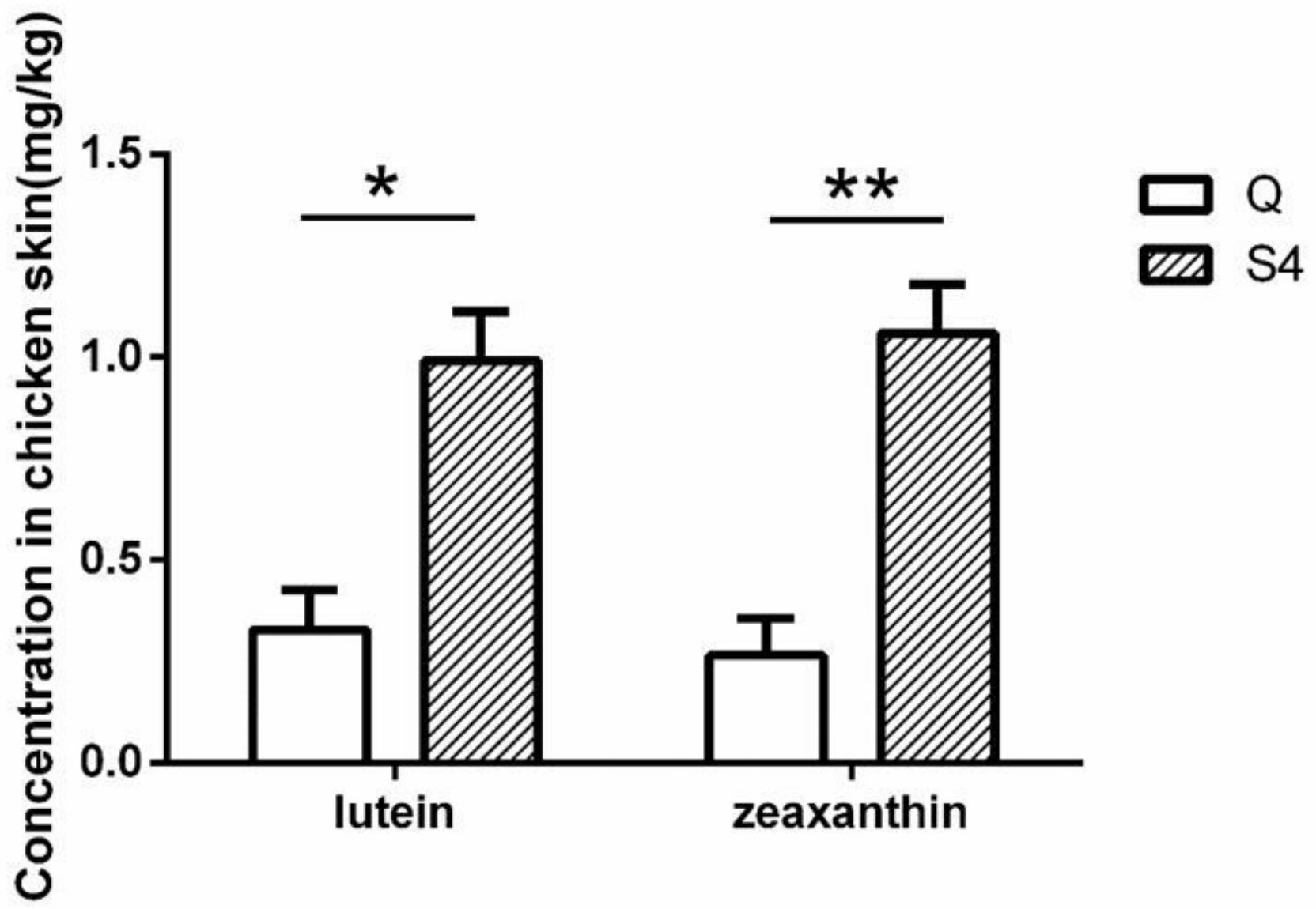

Figure 1

Concentrations of lutein and zeaxanthin in skin from chickens differing in their skin color by the HPLC. Data are expressed with means $\pm S E(n=3)$. Q represent the Qing jiao ma as white skin chicken, $S 4$ represent the Guangxi Huang as yellow skin chicken. * and ** Indicate significantly differences between different breeds (*: $P \leq 0.05, * *: P \leq 0.01)$. 


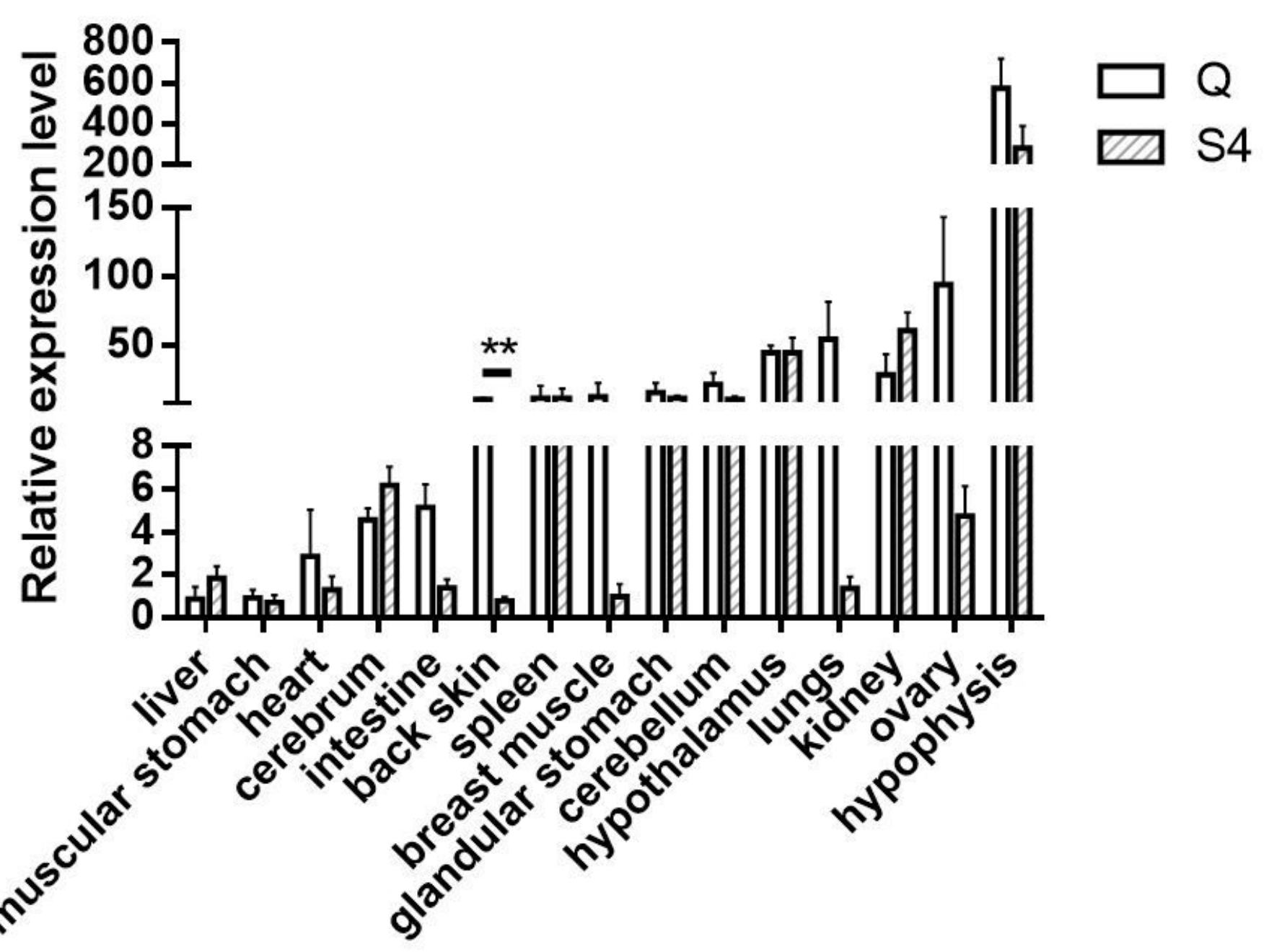

Figure 2

BCO2 expression level in different chicken tissues in the Qingjiao Ma (Q) and Guangxi Huang (S4) chicken breeds. Relative expression analyses in 15 tissue samples of BCO2 gene were normalized to the geometric average of ACTB ( $\beta$-actin) and GAPDH genes. Error bars represent the SE, ** Indicate significantly differences between different breeds on the same tissue $(P \leq 0.01)$. 


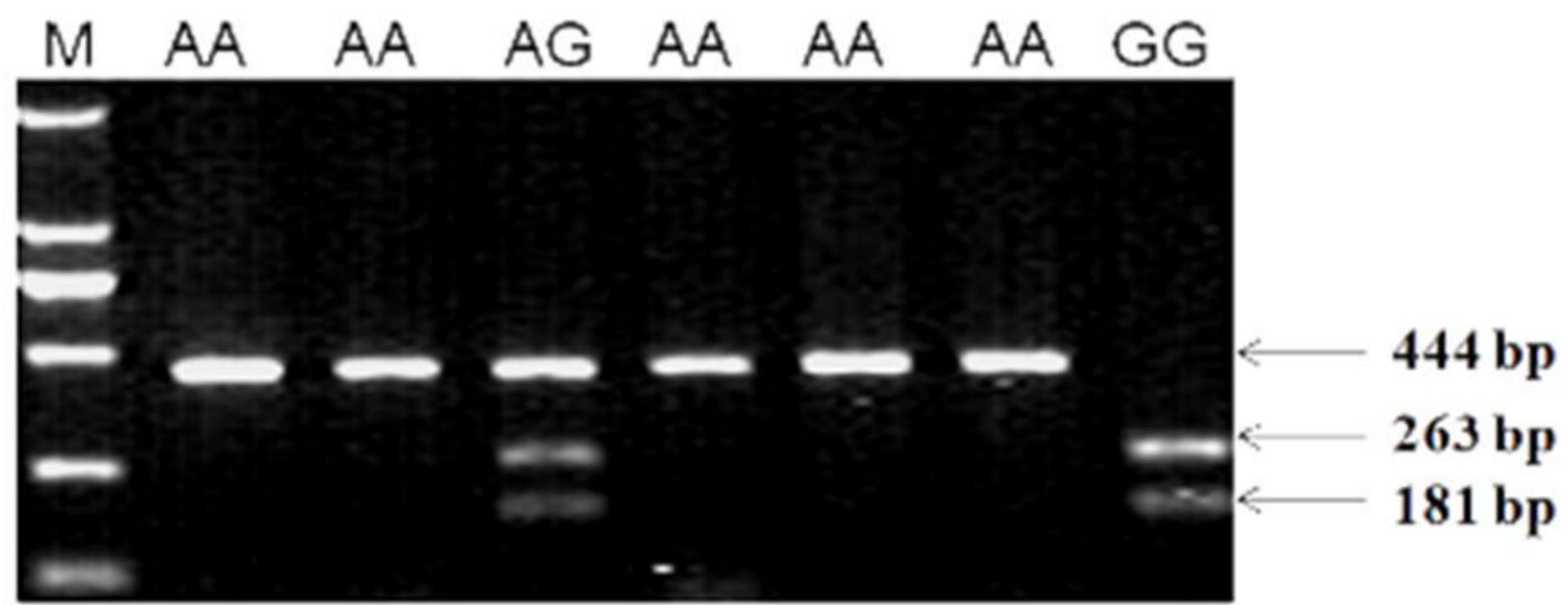

\section{Figure 3}

Agarose gel electrophoresis result of PCR-RFLP. The electrophoresis patterns obtained after digestion with Sdul endonuclease at the c.890A $>$ G locus. Agarose gel electrophoresis (1.5\%) image showing the DNA restriction fragment patterns indicative of polymorphisms in $\mathrm{BCO} 2$ gene after amplification with the primer pair YSD-F/R. The genotypes are shown at the top of the lanes, M, Marker DL2000 DNA Ladder (TaKara). 


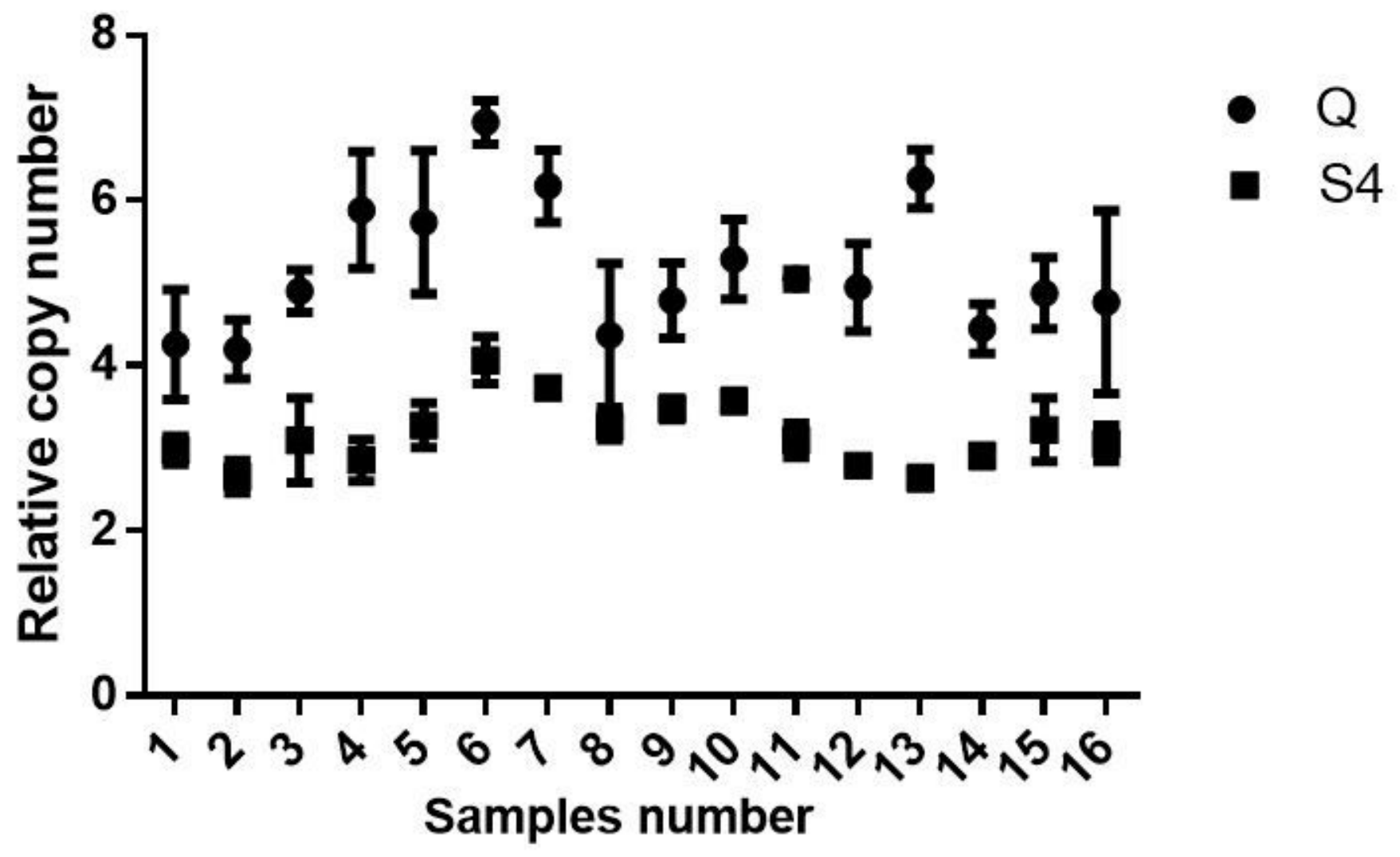

Figure 4

Copy number variation of BCO2 in back skin. Detected by TaqMan Real-time PCR. Q: Qing jiao ma as white skin chicken, S4: Guangxi Huang as yellow skin chicken. 